\title{
Plants with conservation interest in the Complutense University's Biological Field Station
}

\author{
Elena Castoldi, Alberto Benavent \& José Antonio Molina (*)
}

\begin{abstract}
Castoldi E., Benavent A. \& Molina J.A. Plants with conservation interest in the Complutense University's Biological Field Station. Lazaroa 35: 203-207 (2014).

Nine species with conservation interest are recorded at the Complutense University's Biological Field Station. These are the following: a) with regional interest: Ilex aquifolium L., Lilium martagon L., Sorbus latifolia (Lam.) Pers., and Taxus baccata L. (sensitive to habitat alteration); Juncus bulbosus L., Prunus padus L. subsp. padus, and Ranunculus valdesii Grau (vulnerable); Malus sylvestris (L.) Mill. (species of special interest); b) with European interest: Anacamptis morio (L.) R.M. Bateman, Pridgeon \& M.W.Chase (near threatened).
\end{abstract}

Keywords: Conservation status, Habitats Directive, In situ conservation, Threatened species management.

Resumen: Castoldi E., Benavent A. \& Molina J.A. Plantas con interés de conservación en la Estación Biológica de la Universidad Complutense. Lazaroa 35: 203-207 (2014).

Se dan a conocer nueve especies con interés de conservación que alberga la Estación Biológica de la Universidad Complutense de Madrid. Estas son: a) de interés regional: Ilex aquifolium L., Lilium martagon L., Sorbus latifolia (Lam.) Pers. y Taxus baccata L. (sensible a la alteración del hábitat); Juncus bulbosus L., Prunus padus L. subsp. padus y Ranunculus valdesii Grau (vulnerable); Malus sylvestris (L.) Mill. (especie con interés especial); b) de interés europeo: Anacamptis morio (L.) R.M. Bateman, Pridgeon \& M.W.Chase (casi amenazada).

Palabras clave: conservación in situ, Directiva Hábitats, Estado de conservación, Gestión de especies amenazadas.

Biological field stations (BFSs) are generally relatively well-conserved sites supporting basic and applied research into natural ecosystems (Whitesell \& al., 2002). They serve as places where ecosystems can be studied in a variety of ways, and potentially act as a key link between researchers, policy-makers and the general public. BFSs have therefore been set up around the world at an increasing rate (LOHR \& al., 1995). The educational value of BFSs has long been recognized and promoted (BRUNT \& MichENER, 2009; HodDer, 2009; WyMAn \& al., 2009), and the association of these stations with universities provides an optimal framework for both educational and research activities (GINETSINSKAJA, 1995). BFSs are also often areas of biodiversity conservation (EISNER, 1982), serving as both re- fuges for threatened species and as a space for conducting active conservation programmes in the fields of endangered species, habitat loss and fragmentation, and fire processes (LOHR \& al., 1995), among others.

The UCM Biological Field Station (UCMBFS) is located in the El Paular valley close to Rascafría (1200 m.a.s.1., 4054’'N, 35'' W, Madrid, Spain) within the peripheral protection zone of the Sierra de Guadarrama National Park. It occupies an extension of about 50 ha. The dominant plant landscape consists of a mixed forest of melojo-oak -Quercus pyrenaica Willd.- and Scots pine -Pinus sylvestris L.- (CASTOLDI \& Molina, 2012; LóPEZ-SÁEZ \& al., 2013) most likely as a consequence of Scots pine forestry (CASTOLDI \& al., 2013; CAstoldi \& Molina, 2014a) in a po-

\footnotetext{
* Departamento de Biología Vegetal II. Facultad de Farmacia. Universidad Complutense de Madrid. E-28040 Madrid, Spain. E-mail: ecastold@ucm.es, alberban@ucm.es jmabril@ucm.es
} 
tential area of $Q$. pyrenaica forest (RIVAS-MARTíNEZ, 1982; FERNÁNDEZ-GONZÁLEZ, 1992). The current forest management largely involves thinning Scots pine. Pest sanitation by cutting infected branches followed by slash pile burning of wood remnants is a forestry-derived activity. Livestock grazing was abandoned in the territory more than a decade ago. The UCM-BFS currently offers an optimal scenario for developing biological conservation measures in situ.

Twelve plant communities grouped in six vegetation types were identified in the UCM-BFS (CAstoldi \& Molina, 2012). This allowed us to distinguish two natural habitat types in the UCMBFS with interest for conservation in Europe -European Directive 92/43/EEC- (ANON., 2013). The habitat corresponding to water courses of plain or montane levels with Ranunculion fluitantis and Callitricho-Batrachion vegetation (habitat code 3260) was identified along a restricted stretch of about $50 \mathrm{~m}$ long in the channel of the Pedrosillo stream. The mixed forest of $Q$. pyrenaica and $P$. sylvestris which covers more than $80 \%$ of the Station can be considered as closely related to the habitat type corresponding to NW Iberian oak woods of Quercus pyrenaica (habitat code 9230). The management of this forest should seek to promote the development of old-growth $Q$. pyrenaica stands which would increase their value of conservation (BARBOUR \& al., 2007).
At the species level, 280 plant species have been identified in the UCM-BFS by CASTOLDI \& Molina (2014b), although their conservation interest has yet to be assessed. Our study aims to detect which of these species require specific conservation action. For this purpose, we considered the protection level specified in the Madrid regional legislation (ANON., 1992), the Spanish atlas and red book of vascular plants (BAÑARES \& $a l ., 2010)$, and the European red list of vascular plants (BILZ \& al., 2011). The nomenclature of taxa follows CASTROviejo \& al. (1986-2013) or KRETZSCHMAR \& al. (2007) -Anacamptis-.

We identified nine species with conservation interest in the UCM-BFS (Table 1). Eight of them are considered as threatened in the Madrid Region (ANON., 1992) of which four fall under the category of sensitive to habitat alteration (Ilex aquifolium L., Lilium martagon L., Sorbus latifolia (Lam.) Pers., and Taxus baccata L.); three are vulnerable (Juncus bulbosus L., Prunus padus L. subsp. padus, and Ranunculus valdesii Grau); and one is a species of special interest (Malus sylvestris (L.) Mill.). In addition, one species, Anacamptis morio (L.) R.M. Bateman, Pridgeon \& M.W. Chase, is considered as near threatened in the European red list of vascular plants (BILZ \& al., 2011). A detailed description of their presence in the UCM-BFS and current threats is provided below.

Table 1

Species with conservation interest in the UCM-BFS ranked by their conservation status.

\begin{tabular}{lll}
\hline Species (Family) & Distribution & Conservation status \\
\hline Ilex aquifolium L. (Aquifoliaceae) & S \&W Europe ${ }^{1}$ & Sensitive to habitat disturbance $^{3}$ \\
Lilium martagon L. (Liliaceae) & C \& S Europe 1 $^{1}$ & Sensitive to habitat disturbance $^{3}$ \\
Sorbus latifolia (Lam.) Pers. (Rosaceae) & SW Europe ${ }^{1}$ & Sensitive to habitat disturbance $^{3}$ \\
Taxus baccata L. (Taxaceae) & Most of Europe ${ }^{1}$ & Sensitive to habitat disturbance $^{3}$ \\
Juncus bulbosus L. (Juncaceae) & Most of Europe ${ }^{1}$ & Vulnerable $^{3}$ \\
Prunus padus L. subsp. padus (Rosaceae) & Most of Europe1 & Vulnerable $^{3}$ \\
Ranunculus valdesii Grau (Ranunculaceae) & Endemic to Iberian peninsula ${ }^{2}$ & Vulnerable $^{3}$ \\
Malus sylvestris Miller (Rosaceae) & Most of Europe ${ }^{1}$ & Special interest $^{3}$ \\
Anacamptis morio (L.) R.M.Bateman, & Most of Europe ${ }^{1}$ & Near threatened $^{4}$ \\
Pridgeon \& M.W.Chase (Orchidaceae) & & \\
\hline
\end{tabular}

1Flora Europaea (TUTIN \& al., 1964-1980)

2Flora iberica (GRAU \& LÓPEZ GONZÁLEZ, 1986)

${ }_{3}^{3}$ Madrid regional legislation (CM, 1992)

4European Red List of Vascular Plants (BILZ \& al., 2011) 
Five tree species were found with conservation interest. Of these, Sorbus latifolia is the rarest species in the UCM-BFS, and is represented by a single individual. It is scarce in the Guadarrama Mountains (ORIA DE RUEDA \& al., 2006) where it reaches one of the southernmost localities in Europe (AEDO \& AldASORO, 1998). Due to its genetic characteristics -hybrid origin and apomictic behaviour- measures for its conservation should be considered at the landscape or regional scale. This species is endangered or potentially vulnerable in other countries (JACQUES \& al., 2009). Prunus padus subsp. padus is present with only a couple of individuals concentrated in a meadow margin. This taxon reaches its southernmost limit in its Iberian distribution in the Spanish Central System (BlANCA \& DíAZ DE LA GUARDIA, 1998). Its distribution on a worldwide scale does not appear to be compromised, as it is considered an invasive species in North America (REICHARD, 1994). A few individuals of Malus sylvestris were detected in the UCM-BFS. Its natural regeneration is hindered by grazing and hybridization with cultivated forms of cherry, apple and pear (COART \& al., 2006). Thus after the abandonment of livestock in this area some years ago, it should be safeguarded from proximity to Rosaceae fruit trees. Ilex aquifolium and Taxus baccata are the remaining tree species under conservation threat in the UCM-BFS. Ilex aquifolium is generally scarce in the central and southern Mediterranean areas of the Iberian Peninsula where it occurs at the southern limit of its distribution in association with wet montane conditions (CostA \& al., 1997). Although it is commonly found in the UCM-BFS in both shrubby and arboreal forms, its distribution should be monitored. Taxus baccata is widely distributed in the north of the Iberian Peninsula (SANZ \& al., 2009). It is known to be a relict species from earlier climatic periods, restricted to mountain ranges in the central plateau of Iberia (GoNZÁLEZ-MARTínEZ \& al., 2010). This species is frequently found in the UCM-BFS as a consequence of both natural individuals and specimens planted as part of a recent reforestation programme.

Four herbaceous species with conservation interest were found. Lilium martagon is an endangered and protected species in many European countries. Within the Iberian Peninsula it is distributed in its northern half (GÜEMES, 2013). This is the plant whose survival is most at stake in the UCM-BFS. Only three individuals were found, all of which were affected by insect pests attacking flowering plants which prevented seed production. Thus the main recuperation measure should involve pest elimination followed by microhabitat management for seedling recruitment in order to increase the population size. Ranunculus valdesii is an Iberian endemism restricted to the Guadarrama Mountains and the Basque Country (GRAU \& LóPEZ GONZÁLEZ, 1986). It is a very rare species in the El Paular valley (FERNÁNDEZ-GONZÁLEZ, 1988) where the UCM-BFS is located. We found some individuals, sparsely distributed in the study area, forming part of the forest understory. Conservation measures should be studied to determine the growth rates and viability of populations. In spite of its regional status, conservation of Juncus bulbosus does not appear to be compromised due to its widespread distribution at the national, regional and local level (FERNÁNDEZ-GONZÁLEZ, 1988; ROMERO ZARCO, 2010). It was found in peaty margins of rivulets and ponds. Anacamptis morio, considered in European legislation as near threatened, is dispersed throughout the Iberian Peninsula (AEDO, 2005). In the UCM-BFS, it was sporadically found in wet grasslands. At the landscape scale, its conservation does not appear to be under threat (FERNÁNDEZ-GONZÁLEZ, 1988). However, at a local scale, the current absence of livestock grazing is likely to lead to a reduction in grasslands habitats with the consequent threat to this species.

In order to preserve the current biodiversity, any plantation within the UCM-BFS should be avoided. The traditional thinning of Scots pine currently carried out in the UCM-BFS should seek to preserve the threatened plant species in the Station, and also promote the existence and conservation of the two habitat types with European interest for conservation identified in the UCM-BFS. Thus considering the degree of protection specified in the aforementioned documents, and the growth, health and distribution of the nine plant species with conservation interest found in the study area, we strongly encourage UCM-BFS managers to develop a conservation programme for these species. 


\section{REFERENCES}

Aedo, C. - 2005- Orchis L. - In: Aedo, C. \& Herrero, A. (Eds.). Flora iberica 21. Pp. 114-146. R. Jard. Bot., CSIC, Madrid.

Aedo, C., Aldasoro, J.J. - 1998 - Sorbus L. - In: Muñoz Garmendia, F. \& Navarro, C. (Eds.). Flora iberica 6. Pp. 414-429. R. Jard. Bot., CSIC, Madrid.

Anonymous - 1992- Decreto 18/1992, de 26 de marzo, por el que se aprueba el Catálogo Regional de Especies Amenazadas de Fauna y Flora Silvestres y se crea la categoría de árboles singulares - Bol. Of. Com. Madrid 85.

Anonymous - 2013 - Interpretation manual of European Union Habitats - European Commission, EUR 28. DG Environment.

Bañares, Á., Blanca, G., Güemes, J., Moreno, J.C. \& Ortiz, S. (Eds.) - 2010 - Atlas y libro rojo de la flora vascular amenazada de España. Adenda 2010 - Dirección General de Medio Natural y Política Forestal (Ministerio de Medio Ambiente, y Medio Rural y Marino) - Sociedad Española de Biología de la Conservación de Plantas, Madrid.

Barbour, M.G., Sanchez-Mata, D., Rodríguez-Rojo, P. Barnhart, S., Ugurlu, E., Llamas, F. \& Loidi, J. 2007- Age structure of young- and old-growth Quercus pyrenaica stands in Spain - Phytocoenologia 37: 583 598.

Bilz, M., Kell, S.P., Maxted, N. \& Lansdown, R.V. 2011 - European red list of vascular plants - Publ. Off. Europ. Un., Luxembourg.

Blanca, G. \& Díaz de la Guardia, C. - 1998- Prunus L. - In: Muñoz Garmendia, F. \& Navarro, C. (Eds.). Flora iberica 6. Pp 444-466. R. Jard. Bot., CSIC, Madrid.

Brunt, J.W. \& Michener, W.K. - 2009- The resource discovery initiative for field stations: enhancing data management at North American Biological Field Stations - BioSci. 59: 482-487.

Castoldi, E. \& Molina, J.A. - 2012-Vegetation composition of the UCM Biological Field Station (Finca de Ontalba) - Observ. Medioamb. 15: 115-123.

Castoldi, E. \& Molina, J.A. - 2014a - Effect of seed mass and number of cotyledons on seed germination after heat treatment in Pinus sylvestris L. var. iberica Svoboda Forest Syst. 23 (3). DOI 10.5424/fs/2014233-05480.

Castoldi, E. \& Molina, J.A. -2014b - Flora de la Estación Biológica UCM "Finca de Ontalba" - E-prints Complutense, Univ. Complutense, Madrid.

Castoldi, E., Quintana, J.R., Mata, R.G. \& Molina, J.A. 2013 - Early post-fire plant succession in slash-pile prescribed burns of a sub-Mediterranean managed forest - Plant Ecol. Evol. 146 (3): 272-278.

Castroviejo, S. (Coord.) -1986-2013 - Flora Ibérica. Plantas vasculares de la Península Ibérica e Islas Baleares. Vol. I-VIII, X-XV, XVII-XVIII, XX, XXI - R. Jard. Bot., CSIC, Madrid.
Coart, E., Van Glabeke, S., De Loose, M., Larsen, A.S. \& Roldán-Ruiz, I. -2006-Chloroplast diversity in the genus Malus: new insights into the relationship between the European wild apple (Malus sylvestris (L.) Mill.) and the domesticated apple (Malus domestica Borkh.) Mol. Ecol. 15: 2171-2182.

Costa, M., Morla, C. \& Sainz, H. (Eds.) - 1997 - Los bosques Ibéricos. Una interpretación geobotánica - Ed. Planeta, Barcelona.

Eisner, T. - 1982 - For love of nature: exploration and discovery at biological field stations - BioSci. 32: 321-326.

Fernández-González, F. - 1988 - Estudio florístico y fitosociológico del Valle del Paular - Mem. Doc. (ined.). Biología. Univ. Complutense, Madrid.

Fernández-González, F. - 1991 - La vegetación del valle del Paular (Sierra de Guadarrama, Madrid), 1 — Lazaroa 12: $153-272$.

Ginetsinskaja, T.A. - 1995 - The creation of the first marine biological stations in North Russia - Helgoländer Meeresun. 49: 459-463.

González-Martínez, S.C., Dubreuil, M., Vendramin, G.G., Sebastiani, F. \& Mayol, M. - 2010- Spatial genetic structure of Taxus baccata L. in the western Mediterranean Basin: past and present limits to gene movement over a broad geographic scale - Mol. Phylogenet. Evol. 55: 805-815.

Grau, J. \& López González, G. -1986- Ranunculus L. sect. Ranunculus. In: Castroviejo, S., Lainz, M., López González, G., Montserrat, P., Muñoz Garmendia, F., Paiva, J. \& Villar, E. (Eds.). Flora iberica 1: 301-308. R. Jard. Bot., CSIC, Madrid.

Güemes, J. -2013 - Lilium L. In: Talavera, S., Andrés, C., Arista, M., Fernández Piedra, M.P., Rico, E., Crespo, M.B., Quintanar, A., Herrero, A. \& Aedo, C. (Eds.). Flora iberica. Pp. 20: 10-15. R. Jard. Bot., CSIC, Madrid.

Kretzschmar, H., Eccarius, W. \& Dietrich, H. -2007- The orchid genera Anacamptis, Orchis, Neotinea. EchinoMedia, Bürgel.

Hodder, J. - 2009- What are undergraduates doing at biological field stations and marine laboratories? - BioSci. 59: 666-672.

Jaques, D., Vandermijnsbrugge, K., Lamaire, S., Antofie, A. \& Lateur, M. - 2009- Natural distribution and variability of wild apple (Malus sylvestris) in Belgium Belg. J. Bot. 142: 39-49.

Lohr, S.A., Connors, P.C., Sanford, J.A. \& Clegg, J.S. (Eds.) - 1995 - A new horizon for biological field stations and marine laboratories: results of a joint OBFSNAML workshop - Rocky Mount. Biol. Lab., Misc. Publ. 3.

López-Sáez, J.A., Sánchez-Mata, D., Alba-Sánchez, F., Abel-Schaad ,D., Gavilán, R.G. \& Pérez-Díaz S. 2013 - Discrimination of Scots pine forests in the Ibe- 
rian Central System (Pinus sylvestris var. iberica, Pinaceae) by means of pollen analysis. Phytosociological considerations - Lazaroa 34: 191-208.

Oria de Rueda, J.A., Martínez de Azagra, A. \& Álvarez, A. -2006 - Botánica forestal del género Sorbus en España - Invest. Agrar. Sist. Recur. For. 15(1): 166-186.

Reichard, S. - 1994- Assessing the potential of invasiveness in woody plants introduced in North America Univ. Washington, Ph.D. diss.

Rivas-Martínez, S. -1982- Mapa de las series de vegetación de la provincia de Madrid. Publ. Serv. Forestal del Medio Ambiente y Contra Incendios, Diputac. Provinc. Madrid.

Romero Zarco, C. - 2010 - Juncus L. In: Talavera, S., Gallego, M.J., Romero, C., Zarco \& Herrero, A. (Eds.).
Flora iberica 17. Pp. 123-187. Real Jard. Bot., CSIC, Madrid.

Sanz, R., Pulido, F. \& Nogués-Bravo, D. -2009- Predicting mechanisms across scales: amplified effects of abiotic constraints on the recruitment of yew Taxus baccata. Ecography 32: 993-1000.

Tutin, T.G., Heywood, V.H., Burges, N.A., Valentine, D.H., Walters, S.M., Webb, D.A. - 1964-1980 - Flora Europaea 1-5. Cambridge Univ. Press.

Whitesell, S., Lilieholm, R.J. \& Sharik, T.L. - 2002- A global survey of Tropical Biological Field Stations BioSci. 55: 55-64.

Wyman, R.L., Wallensky, E. \& Baine, M. -2009- The activities and importance of international field stations BioSci. 59: 584-592.

Received: 18 June 2014

Accepted: 3 November 2014 